\title{
DEL DIARIO DE \\ MARCELO BARBAGALLO
}

Francisco García Marañón*

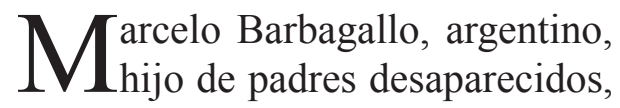
caminó por Sudamérica antes de morir en 2006. Los familiares que le quedaron lo recordaban como un chico aislado e introvertido, pero noblemente amoroso. Aun cuando la dictadura militar lo marcó de por vida, Marcelo no perdió ciertos hilos de comunicación que lo conectaban con sus padres ausentes: afanes y pasiones por algunos personajes históricos que los identificaban. De aquella travesía se dejó constancia en una serie de cuadernos escritos a modo de diario, de los cuales se transcriben las siguientes letras.

\section{Bitácora de viaje}

26 de mayo, Vallegrande, Bolivia

Papá cuéntame otra vez esa historia tan bonita de aquel guerrillero loco que mataron en Bolivia.

Ismael Serrano

Descanso medio apacible en un alojamiento esquinado en la plaza de Vallegrande. Volví ayer de la Higuera a las once de la noche, pasaditas -ahora son las seis de la mañana-después de un viaje en camión

* Escritor. 
de carga que me provocó una dolencia en la boca del estómago. Esta madrugada, en el cuarto de al lado, una pareja garchó a todo tren. Se escuchaban los gemidos de la mina y de pronto se me confundieron con las campanadas de las cinco de la mañana. La mina siguió gimiendo hasta que escuché los espasmos del tipo, luego juntos, y al rato silencio sepulcral. Afuera los encargados de la limpieza barren la basura acumulada del domingo; sus uniformes de la oficina de limpia son unos bucitos tejidos y disparejos de colores. Me tocó una habitación calientita, por fortuna.

Al final, el saldo físico de la visita a la Higuera se traduce en una raspadura en la cara externa de la espinilla, un tironcito en la ingle, picaduras, espero que ninguna de vinchuca, y la molestia estomacal. La noche estrellada mostraba la hermosa luz de la Vía Láctea, nebulosa y tupida de luceros; los de la Higuera la llaman El río y las estrellas son Las rocas. Así salí del lugar, re-contento. Los primeros cincuenta minutos del viaje a pie, esquinado al lado izquierdo de la caja de carga, mirando la noche guevariana por última vez, satisfecho de haber llegado. Llegamos a Pukará casi una hora después y ahí sí se vino la noche, el frío y el malestar. Acomodé la bolsa de dormir sobre un fardo polvoriento y me senté en la parte lateral de la caja, apoyando sólo las piernas, que hicieron el esfuerzo. En una vuelta bajé el tórax e intenté seguir el rumbo con el abdomen y de inmediato sentí el dolorcito en la boca del estómago. Me había subido al camioncete con el tirón en la ingle. Esta vez, no como el viernes, jugué con garra, a lo Marcelo, gracias al ejemplo del brasilero André, que llegó apenitas con su chica Lula unas horas antes de irme. Los bolitas juegan duro pero el picadito fue nuestro y les dimos baile hasta que me tironeé y preferí salir de la cancha. Ahora sí mordieron el polvo los chicos, se encabronaron y todo. Luego de sufrir volví a Vallegrande re-tarde y a buscar posada con el martirio de la mochila a la espalda y todo abollado. Caí acá no tanto por el precio, sino que ya no aguanté más y, para acabarla, los amantes se me meten entre las sábanas.

Retomo: La Higuera es un caserío menos que miserable, viven ahí casi cincuenta personas; no hay luz y por fortuna llegaron los médicos cubanos a evitar que los niños se mueran de diarrea. El lugar de pronto 
me chocaba. El guía, Melanio, aseguraba conocer más o menos la historia de cómo había sido la batalla final, pero cuando me llevó a la escuela y le hice un par de preguntas me di cuenta de que no. La información medio que la van pescando de oídas al más puro estilo bardo. La escuela a donde llevaron preso al comandante y donde lo mataron fue arreglada; tenía dos puertas y sólo dejaron una, todo el interior es hoy un museo. Había dos ambientes que servían de salones y ahora es un espacio amplio porque rompieron la pared que los dividía. Se me complicó identificar dónde lo enclaustraron y cuando le pedí al guía que me diera dos minutos para orar me desorienté, así que no supe a quién rezaba. Se me fue la tarde en la visita a la escuelita y antes del anochecer los chicos del pueblo, unos nueve, me invitaron a jugar un picadito, primero tranqui pero luego con apuesta de por medio, a 50 centavos piocha, que sólo pagan los extraños, por cierto. Re-guachos los chicos porque te ponen a jugar con los más pavos. Ese día me dieron un par de patadas, ya al juego de la apuesta le meten más galleta. Al final ni se veía y ellos tan lozanos, ocupando el único espacio vivo del pueblo, donde también está el consultorio que instalaron los cubanos. Me acordé del Diego cuando contaba que jugaba en la noche y ni se veía, y al día siguiente, lleno de luz, todo era más fácil.

Esa noche me tocó la primera de tres hermosuras: una noche estrellada de la Higuera a todo lo que da. Al entrar al albergue, para mí solo, leí en el libro de visitantes que había vinchucas y me agarró la mona. No quise dormir; le pregunté a los cubanos si sabían algo al respecto: hasta ese instante sólo habíamos cruzado un par de palabras y uno de ellos, el negrón, me contestó que era probable. "Detrás hay un gallinero y ése es su lugar”. Me había quedado de ver con el guía a las ocho de la mañana del día siguiente, así que no tuve más remedio que irme a dormir. Saqué la bolsa y me clavé dentro completito. Dejé la campera como toldo por si asomaba la cabeza y me dormí. Estaba hecho bolsa, el pie izquierdo con ampollas del tamaño de la planta, desde el dedo gordo hasta el talón, y en el lado derecho la raspadura que jodió toda la noche. En la tarde, cuando le recé al comandante, le dije que al fin llegué después de tanto tiempo y se me salieron las lágrimas. Parece que le importó 
tres pepinos porque ni sus luces. A la mañana siguiente no podía moverme. Fui a buscar al guía, la señora medio que me dio de desayunar -un té y galletas-, y marchamos a la quebrada y a Abra del Batán. Hicimos el camino debajo de un sol a tope. El tipo me explicó como si se hubiese aprendido la lección, repitiendo lo que había escuchado decir: "aquí mataron al primero, aquí al segundo; acá al tercero"; no conocía los nombres y debió haber sido, por lógica, justo al revés: primero el de hasta arriba, Miguel; a media bajada Julio, cerquita de él, y luego Coco -sobre los hombros de Urbano-, quien decía el guía que fue el primer muerto. Ahí empecé a dudar. Subimos a la loma de Abra del Batán, desde donde podía apreciarse el valle. La vista era precisamente la misma que yo tuve el día anterior cuando vi el pueblo por primera vez. El tipo me contó dónde se apostaron los militares, cómo emboscaron a la vanguardia y cómo escapó el Che, cuando deja correr las mulas río abajo y él bordea la cañada. A los ojos se entiende tal cual.

Tantos años imaginando el lugar, sin referencias específicas más que las ofrecidas en el diario. Letras, ideas, imágenes, paisajes que mi cabeza incapaz se negó a vislumbrar. Acceder al lugar e ir comprendiendo, ir observando los movimientos como un tablero de ajedrez, con huidas, tropas y emboscadas. Cada cuadro del tablero una llanura o una quebrada. Para llegar a la quebrada del Churo -acá no es Yuro y Guevara es Yevara-, tardamos un rato. Fuimos bajando, rodeando las chocleras, las higueras espinosas terribles que refiere Pacho, y las condiciones abominables: la angustia, la muerte cerca, oliendo a pólvora. Bajamos la vereda hasta un medio vallecito donde se halló el sembradío famoso de papas, y donde, según el cuento, acampó el Che; no había duda en eso, incluso me pareció haber descubierto, en la lejanía de la cañada y medio escondido por el follaje, el farallón que trepó como gato, a donde el inútil del guía no me quiso llevar.

El tipo estaba empecinado en que ahí había combatido el Che y yo que no, que debió ser bastante más abajo. Me parece que en un momento se sintió cercado y sentenció: yo no voy a contar mentiras. No, pero tampoco me dirás verdades sobre la última batalla, la que soñé con dolor desde mi adolescencia. No porque seas mentiroso, vos, sino porque 
no sabés. No me pudo decir dónde subió el Che herido, gracias a los hombros de Willy, ni por dónde salieron Pablo y los otros heridos. Me sentí frustrado de haber llegado hasta allá y no contar con el mapa completo. El tipo venía enfermo de catarro. Volvimos, yo con un sinsaborcito y molesto, y él sin gusto ni olfato, quizá. La subida de la quebrada fue mortífera, iba yo echando espuma por la boca porque él se quería volver pronto a casa y caminaba como si lo persiguieran, y yo con los dolores musculares. Subí de a poco y luego le pedí que viéramos la quebrada desde un ángulo más alto. Resultado: mucha caminata y desastre óptico.

Así volví de la zona de guerra, triste, frustrado. Pagué, comí, bebí gaseosa y agua como las últimas de la tierra y me fui para el albergue. Me topé con uno de los cubanos y me preguntó si me sobraba una cuchilla para afeitar; le contesté que no, pero que le regalaba mi navaja. Ahora me voy a barba hasta la vuelta. Muy simpáticos, buenos conversadores, me compartieron su cena, arroz con papas y tomate bajados del mismo paraíso. Llevaban un rato en la Higuera y no habían podido ir a la zona por la guardia. Preguntaron por Argentina y se atrevieron, ya partido el turrón, a imitarme. De lo más cómico porque les salía el che y el vos con olor a ron y azúcar. Yo hice lo propio pero más pareció que canté un tango de Martí. Todos truchos. Cuando volví al albergue me moria de miedo. Mis pantalones estaban podridos y hacía un frío perpetuo. Justo en la soledad del albergue se me ocurrió recordar que una mina escribió que hay fantasmas. Se me subieron las pelotas. La nota estaba fresca, apenas unos meses atrás. Yo invoqué todo el tiempo a los espíritus. Menos mal que eran marxistas. Apagué la luz del albergue, solito, y armé la bolsa a oscuras, todavía para generar mayor atmósfera. Me asomé un par de veces por la ventana, esperando, temiendo que apareciera alguna silueta negra mirando desde afuera, los ojos brillando de fuego y un susto para el infarto. Me escurrí en la bolsa. Esta vez dormí sin la campera encima asegurándome de no sacar los brazos y ocultando la cabeza con apenas un hoyo para respirar. De pronto me habían aparecido picaduras en las piernas sin mosquitos a la vista. No sé cómo pero cerré los ojos y medio que dormí. 
Y despierto acá, en Vallegrande, lleno de pendientes: volver a la Higuera, la de las espinas a la altura de la pantorrilla derecha, clavándose los filos en la costra blanda; la Higuera de las vinchucas, la del picadito vespertino hasta anochecer a 50 centavos la derrota, con patadas, empujones y el handicap de los malitos jugando al lado del forastero; la Higuera de la miseria, del candelero o la lámpara de keroseno. La Higuera del mito. La mítica quebrada del Churo. Y te asomás al escenario y te cagás de risa, de llanto, de bronca. Cómo lo vinieron a asesinar acá, comandante. Los propios nativos huyeron. Quedan 12 o 15 familias de las 50 que lo vieron llegar prisionero y lo vieron salir muerto, en ambos casos con los ojos bien abiertos, como para registrar, como para no olvidar. La Higuera de las imprecisiones y desinformaciones, de las ignorancias, todo junto para hacerlo más confuso aún. Pensé que lo iba a encontrar acá, Ernesto, pero usted se fue de la Higuera, de la quebrada y de Vallegrande hace mucho tiempo. Incluso se fue de mí. ¿Cómo no iba a partir? Veinticinco años tardé en llegar, comandante. Nomás 25. Y ahora no lo encontré aunque, a decir verdad, me morí del espanto cuando me tocó dormir solo en el albergue comunitario sin otra alma, imaginando que algún fantasma explorador se asomaría por la ventana del dormitorio, Miguel quizá, con la cabeza partida; Coco, acaso convulsionándose por culpa de la pleura agujereada; usted mismo, rematado vilmente de un balazo a quemarropa en el pecho.

Es muy probable que usted no haya querido entrar al cielo, comandante; por eso pensé que lo iba a encontrar aún vagando por acá, pero no. Parece que arreó las mulas y enfiló camino abajo ya sin guías estelares. A lo mejor se habrá molestado conmigo, pero no fue con mala intención tutearlo y menos sacralizarlo cuando le escribí en el libro de visitas lo que profesa religiosamente Charly García. Yo también "rezo por vos", Ernesto, si me lo permitís. Si no, también. Nos veremos en algún otro sitio. Me resta aclararte que incluso el hasta siempre tiene final. Qué le vamos a hacer, comandante. Todo termina. Concluyo asegurándote que lo lindo de tu historia no es que te transformés en un santo o un demonio, sino que, lo que legaste, de seguro el último hombre o la última mujer dignos y solidarios de estas tierras lo tomarán en cuenta.

Ya con eso, me parece. 